\title{
MARINA SHORELINE CHANGE DETECTION USING REMOTE SENSING AND GIS
}

\author{
S. Thangaperumal \\ Assistant Professor, Department of Civil Engineering, \\ St.Joseph's College of Engineering, Chennai, Tamilnadu, India \\ Cyril Magimai Antoz A \\ Department of Civil Engineering, \\ St.Joseph's College of Engineering, Chennai, Tamilnadu, India \\ Shivaharan $\mathbf{R}$ \\ Department of Civil Engineering, \\ St.Joseph's College of Engineering, Chennai, Tamilnadu, India
}

\begin{abstract}
Marina is considered as the world's second largest urban beach. It has a stretch of $13 \mathrm{Km}$ including a $6 \mathrm{Km}$ promenade. It has been studied in order to understand shoreline changes and erosion/accretion pattern that have been taken place due to the natural processes and anthropogenic activities. The shoreline is one of the rapidly changing coastal landforms. Shorelines are the key element in coastal GIS and provide the most information on coastal landform dynamics. Therefore, accurate detection and frequent monitoring of shorelines are very essential to understand the coastal processes and dynamics of various coastal features. Multi temporal landsat ( 7 ETM+) satellite images from 2009 to 2019 were used to extract shorelines. The data is processed and analyzed by (Digital Shoreline Analysis System) DSAS an extension tool of ArcGIS. The rate of the shoreline change are calculated by 3 statistical analysis such as (End Point Rate) EPR, (Net Shoreline Movement) NSM and (Linear Regression Rate) LRR. The study had been conducted in summer and winter season and the results obtained are shown in graphs. The result obtained clearly shows Accretion is higher in summer and erosion is higher in winter.
\end{abstract}

Keywords: Erosion, Accretion, Shoreline, Change Detection, Remote Sensing, ArcGIS, Digital Shoreline Analysis System, End Point Rate, Linear Regression Rate, Net Shoreline Movement.

Cite this Article: S Thangaperumal, Cyril Magimai Antoz A and Shivaharan R, Marina Shoreline Change Detection Using Remote Sensing and GIS. International Journal of Civil Engineering and Technology, 11(3), 2020, pp. 85-96.

https://iaeme.com/Home/issue/IJCIET?Volume $=11 \&$ Issue $=3$ 


\section{INTRODUCTION}

Coastal areas are very important for human beings since the beginning of time. Most of the big cities around the world are situated at coastal areas. About one third of the human populations are living in and around the seashore areas. Due to abundant natural resources, urbanization and population rapidly increases on coastal areas. Various development projects were made in shoreline areas which lead to diverse coastal hazards like soil erosion, sea water intrusion, coral bleaching, shoreline change, sedimentation etc.

Coastal landforms are dynamic in nature. They are continuously modified by natural and other man made process. Shoreline is defined as the line of contact between land and water body [5]. Accurate demarcation and monitoring of shorelines necessary for understanding various coastal process [10]. Shoreline delineation is difficult, time consuming and sometimes impossible for entire coastal system when using traditional grand surveying techniques. Over the past few decades, remote sensing and geographical information system techniques have lead to improvements in coastal geo-morphological studies. The development of Remote sensing and GIS technologies are nowadays proved to be the most powerful and reliable tools for shoreline change mapping.

\subsection{Need for Study}

- Human civilization is growing rapidly along the coast worldwide due to abundant natural resources [9]. Climate change and development of infrastructure put pressure on coastal environment and this lead for various coastal hazards like coastal erosion, flooding, sea level rise, sea water intrusion and bio resource degradation.

- So, accurate demarcation and monitoring of shorelines are necessary for understanding various coastal processes.

\subsection{Objectives}

- To prepare the shoreline map for the year of 2009 to 2019 in Marina.

- To analyze the changes in shoreline for the year of 2009 to 2019 in Marina.

- To do statistical analysis for the year 2009 to 2019 on Marina Shoreline.

\section{STUDY AREA}

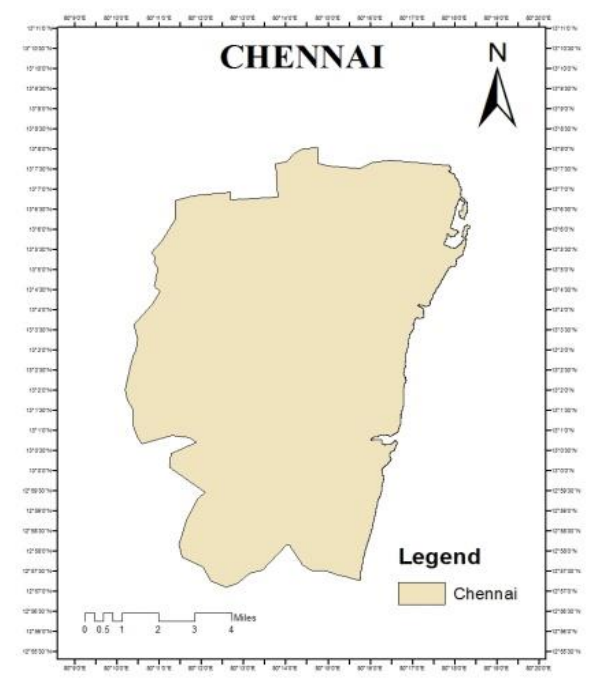

Figure 1 Chennai District Map

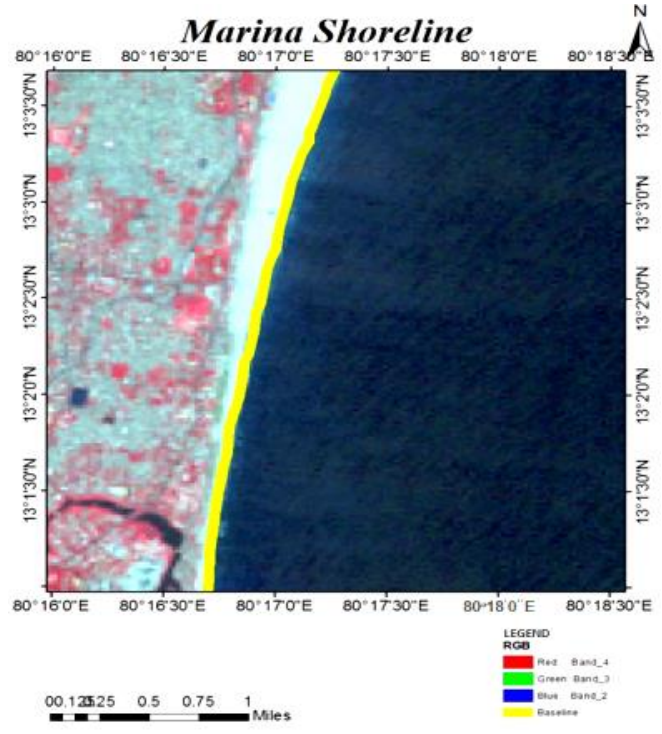

Figure 2 Marina Shoreline Map 
Our study area is marina beach. Marina is the natural urban sandy beach in Chennai, Tamilnadu, India along the Coromandal Coast of Bay of Bengal. The beach runs from the fort St. George in the North to Foreshore Estate in south, making it the longest natural urban beach in the country (Fig $1 \& 2$ ). Marina is primarily sandy, Average width of the beach is $300 \mathrm{~m}(980 \mathrm{ft})$, width at widest stretch is $437 \mathrm{~m}(1434 \mathrm{ft})$.

\section{MATERIALS \& METHODS}

The Shoreline change assessment for Marina beach is studied for a period of 10 years from 2009-2019. Shoreline Multi temporal Satellite data of landsat 7 (ETM+) were downloaded from the website USGS .The Details regarding the satellite and acquisition dates are listed in table 1 .

Table 1 Sources of Data Band Resolution

\begin{tabular}{|c|c|c|c|c|c|c|c|}
\hline$\sum_{\dot{s}}^{\circ}$ & 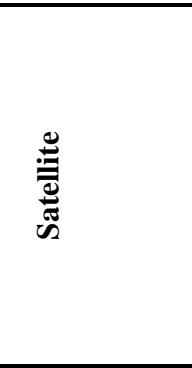 & 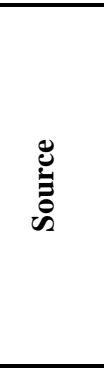 & 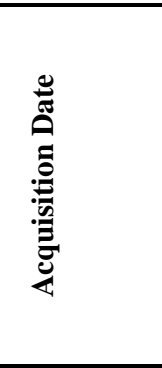 & 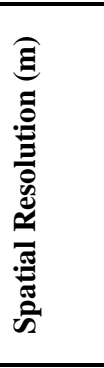 & 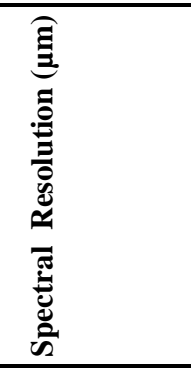 & 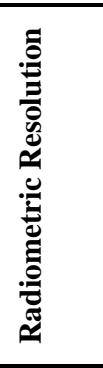 & 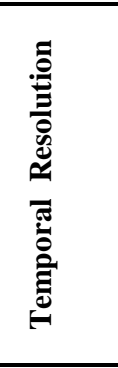 \\
\hline 1. & \multirow{22}{*}{$\begin{array}{c}\text { LANDSAT } 7 \\
(\text { ETM }+)\end{array}$} & \multirow{22}{*}{ USGS } & 08-12-2009 & \multirow{19}{*}{$30 \mathrm{~m}$} & \multirow{11}{*}{$\begin{array}{c}\text { Band 1 } \\
-0.45-0.52 \\
\\
\text { Band2 } \\
0.52-0.6 \\
\text { Band3 } \\
0.63-0.69 \\
\\
\text { Band4 } \\
-0.77-0.99\end{array}$} & \multirow{22}{*}{8 bit } & \multirow{22}{*}{16 days } \\
\hline 2. & & & $27-12-2010$ & & & & \\
\hline 3. & & & 12-11-2011 & & & & \\
\hline 4. & & & 13-10-2012 & & & & \\
\hline 5. & & & 19-12-2013 & & & & \\
\hline 6. & & & $20-11-2014$ & & & & \\
\hline 7. & & & $22-10-2015$ & & & & \\
\hline 8. & & & $27-12-2016$ & & & & \\
\hline 9. & & & 14-12-2017 & & & & \\
\hline 10. & & & $27-12-2018$ & & & & \\
\hline 11. & & & $18-11-2019$ & & & & \\
\hline 12. & & & $23-02-2009$ & & Band5 & & \\
\hline 13. & & & 02-06-2010 & & $1.55-1.77$ & & \\
\hline 14. & & & 02-04-2011 & & Band6 & & \\
\hline 15. & & & $22-06-2012$ & & -10.40 & & \\
\hline 16. & & & $09-05-2013$ & & -12.50 & & \\
\hline 17. & & & $12-05-2014$ & & Band7 & & \\
\hline 18. & & & 29-04-2015 & & $2.09-2.35$ & & \\
\hline 19. & & & $01-05-2016$ & & & & \\
\hline 20. & & & 04-05-2017 & \multirow{3}{*}{$15 \mathrm{~m}$} & Band 8 & & \\
\hline 21. & & & 05-04-2018 & & panchromatic & & \\
\hline 22. & & & $26-05-2019$ & & $0.52-0.90$ & & \\
\hline
\end{tabular}

Shorelines of marina beach are extracted from ArcGIS software from 11 geo-reference landsat satellite image of 2009, 2010, 2011, 2012, 2013, 2014, 2015, 2016, 2017, 2018 and 2019.The data for the analysis is managed in personal geo-database named DSAS in UTM Projection. All input data must be imported and managed within personal geo-database, which also serves as the storage location for the program generated transect feature class and related statistical output files used in analysis must reside in the geo-database. The following steps were carried out for the project as shown in Fig 3. 


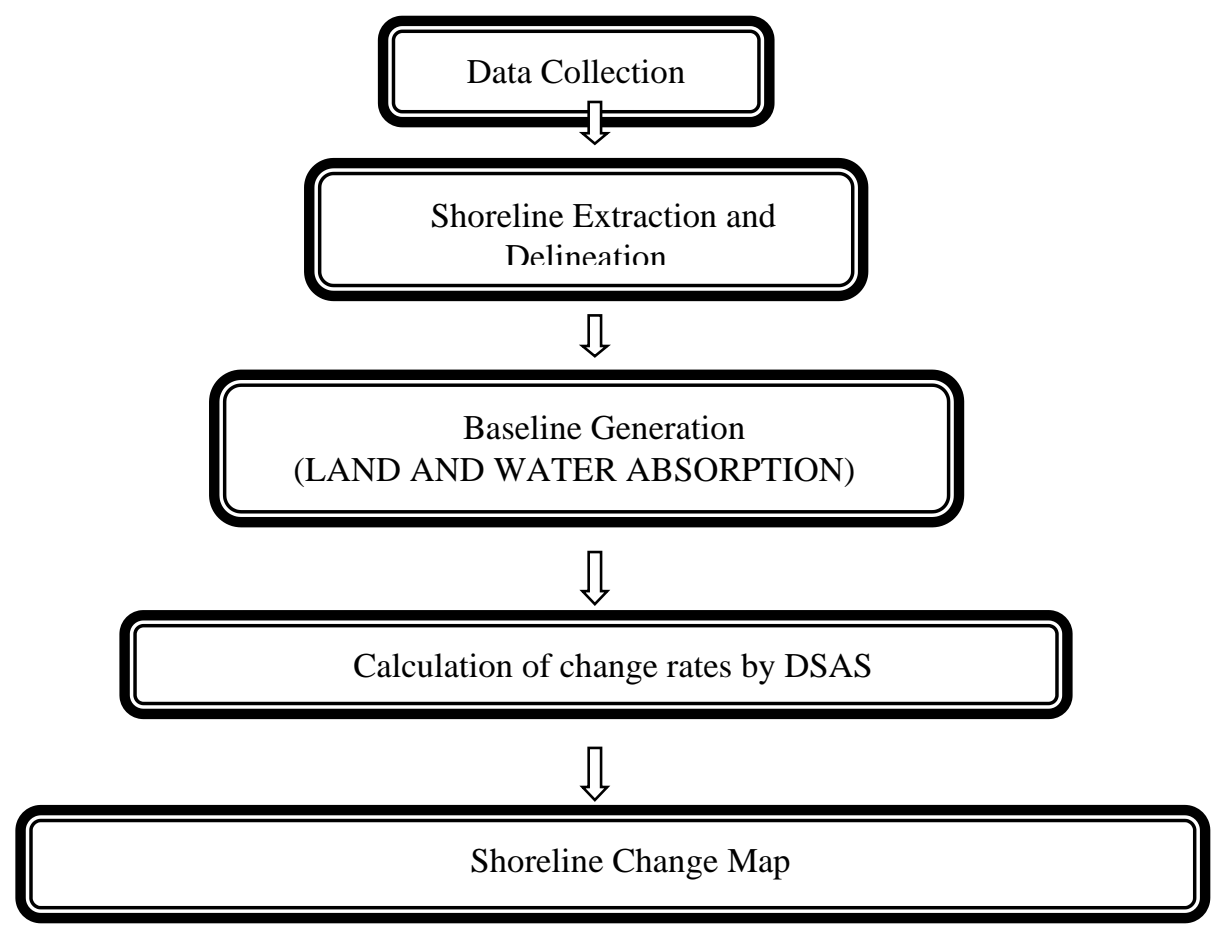

Figure 3 Flow chart

\section{RESULTS AND ANALYSIS}

\subsection{Calculation of Change rate by DSAS}
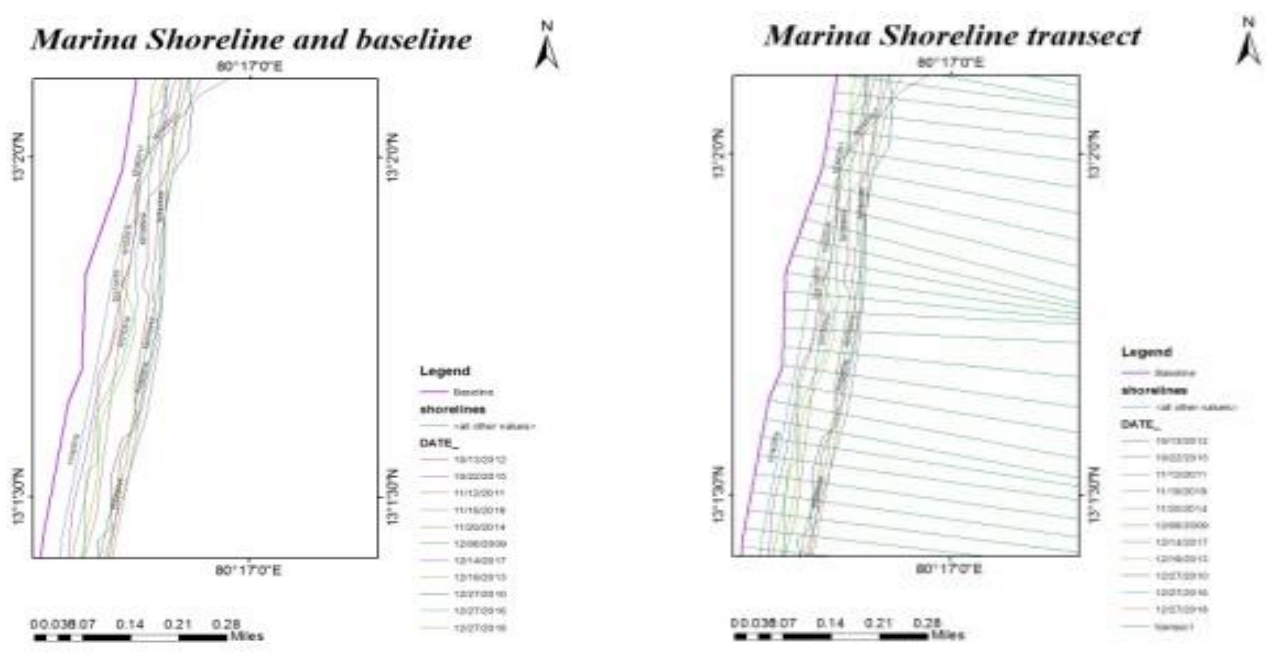

Figure 4 Marina Shoreline and Baseline

Figure 5 Marina Shoreline transect

If Shoreline of various years obtained are assembled in a single file in ArcGIS labeling is done to identify the shoreline of particular year baseline was constructed parallel to the orientation of shoreline, Baseline was constructed as on-shore. Fig 4 Shows the Marina shoreline and baseline created by this process. Transects are constructed with a spacing of $50 \mathrm{~m}$ and smoothing distance of $100 \mathrm{~m}$. These transects are used to calculate shoreline rate of change based on measured difference between shoreline positions through time. Fig 5 shows the transects creation process. 


\subsection{Spatial Change Analysis in Marina Shoreline}

\subsubsection{End Point Rate Analysis for Winter}

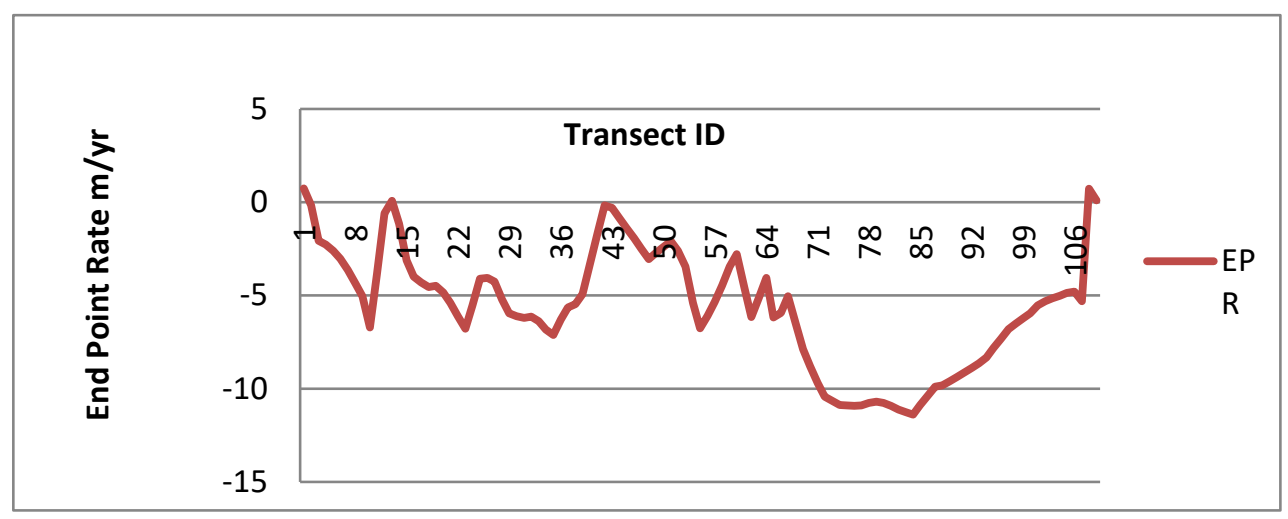

Figure 6 Transect ID Vs End Point Rate Analysis for Winter

End point rate analysis is a short term analysis method. It is very less accurate. Here the marina shoreline is around $6 \mathrm{Km}$ which is divided into 109 transects [10]. Fig 6 shows both erosion and accretion were observed but majority of the transects shows erosion which was observed in 105 transects, only 4 transects shows accretion. They are 1,13,108 and 109.The maximum value of erosion was $-11.39 \mathrm{~m} / \mathrm{yr}$ which was observed in transect ID 84 . The maximum value of accretion was $0.74 \mathrm{~m} / \mathrm{yr}$ which was observed in transect ID 1 .The average of all erosional rates was $-5.86 \mathrm{~m} / \mathrm{yr}$. The average of all accretional rates was $0.41 \mathrm{~m} / \mathrm{yr}$. The average considering all transects was $-5.63 \mathrm{~m} / \mathrm{yr}$.

\subsubsection{End Point Rate Analysis for Summer}

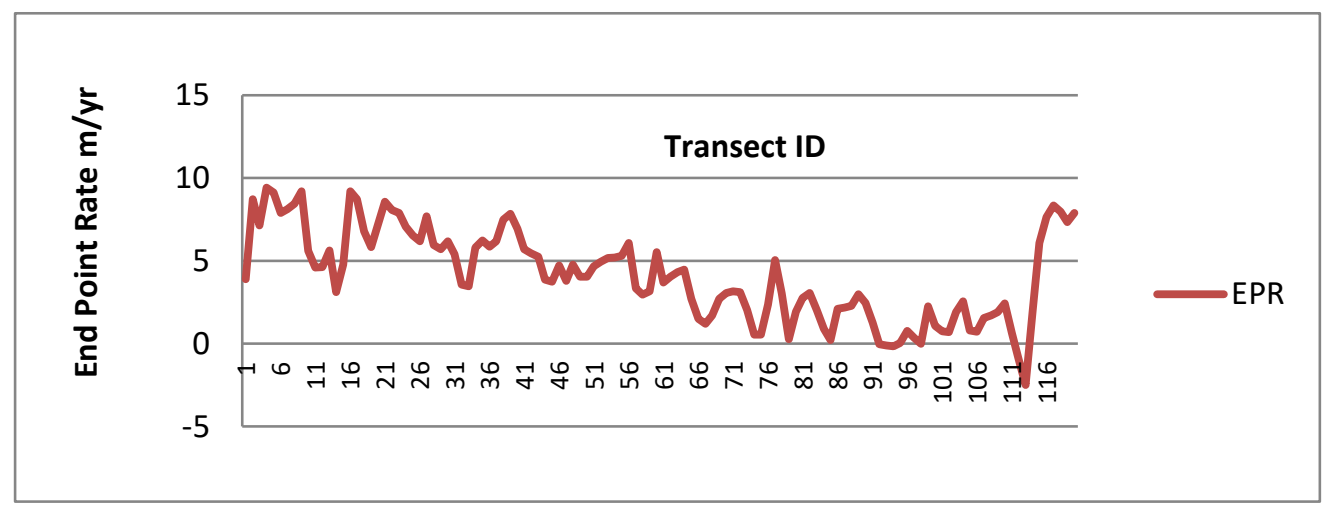

Figure 7 Transect ID Vs End Point Rate Analysis for Summer

Here the marina shoreline is divided into 120 transects. Fig 7 shows Both erosion and accretion were observed but majority shows accretion which was observed in 114 transects, only 6 transects shows erosion. They are 92, 93, 94, 98, 112 and 113 [10].The maximum value of erosion was $-2.5 \mathrm{~m} / \mathrm{yr}$ which was observed in transect ID 113 .The maximum value of accretion was $9.4 \mathrm{~m} / \mathrm{yr}$ which was observed in transect ID 4.The average of all erosional rates was $-0.62 \mathrm{~m} / \mathrm{yr}$. The average of all accretional rates was $4.38 \mathrm{~m} / \mathrm{yr}$. The average considering all transects was $4.13 \mathrm{~m} / \mathrm{yr}$. 


\subsubsection{Linear Regression Rate for Winter}

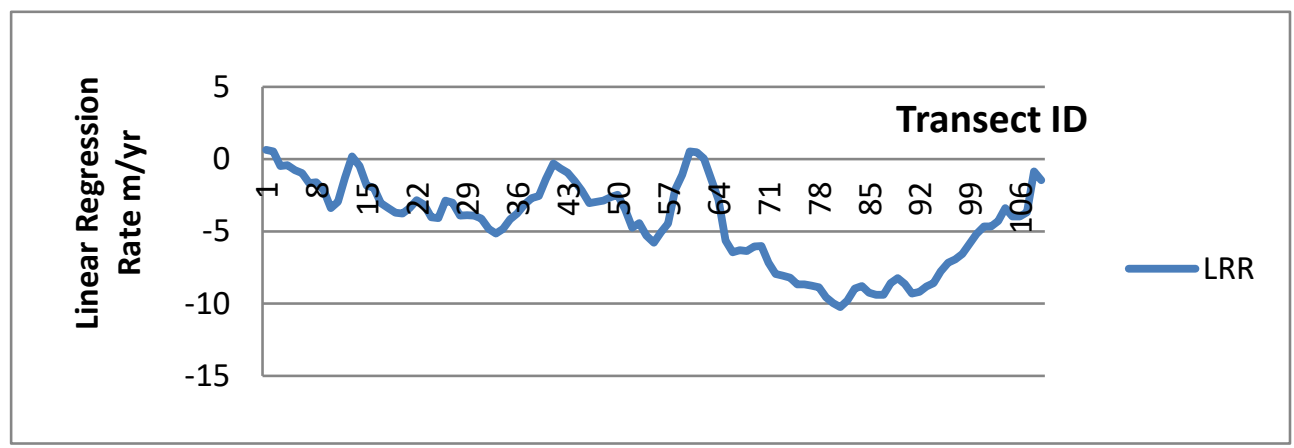

Figure 8 Transect ID Vs Linear Regression Rate for Winter

Linear Regression Rate analysis is an long term analysis method. It is very accurate compared to other methods. Here the marina shoreline is around $6 \mathrm{Km}$ which is divided into 109 transects. Fig 8 Both erosion and accretion were observed but majority shows erosion which was observed in 103 transects, only 6 transects shows accretion. They are 1, 2, 13, 60, 61 and 62.The maximum value of erosion was $-10.24 \mathrm{~m} / \mathrm{yr}$ which was observed in transect ID 81 .The maximum value of accretion was $0.64 \mathrm{~m} / \mathrm{yr}$ which was observed in transect ID 1.The average of all erosional rates was $-4.72 \mathrm{~m} / \mathrm{yr}$. The average of all accretional rates was $0.4 \mathrm{~m} / \mathrm{yr}$. The average considering all transects was $-4.4 \mathrm{~m} / \mathrm{yr}$.

\subsubsection{Linear Regression Rate for Summer}

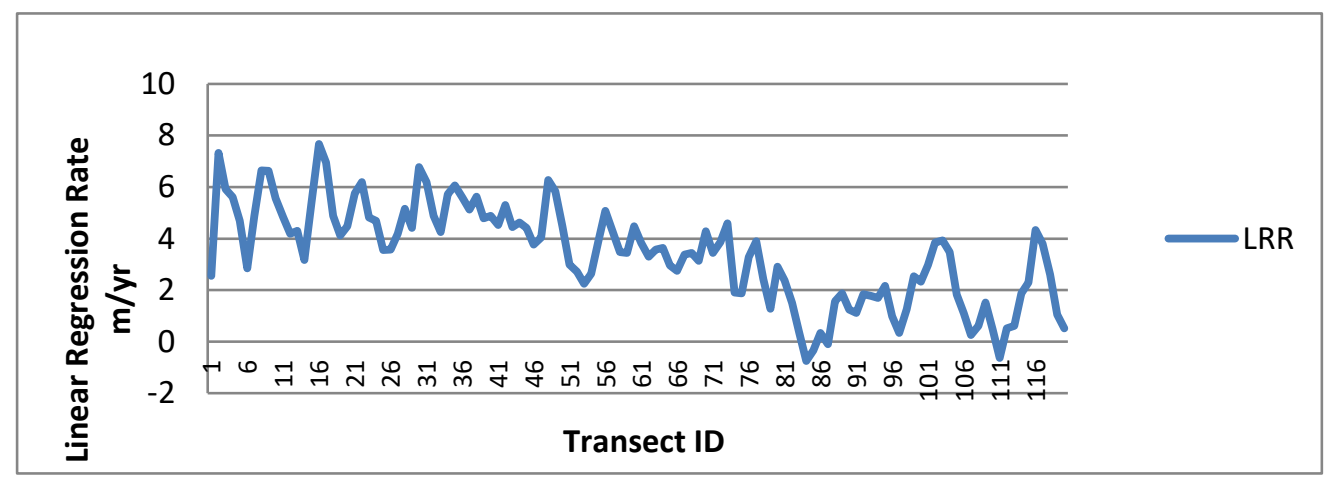

Figure 9 Transect ID Vs Linear Regression Rate for Summer

Figure 9 shows the LRR is the slope of the line. Here the marina shoreline is divided into 120 transects. Both erosion and accretion were observed but majority shows accretion which was observed in 116 transects, only 4 transects shows erosion. They are 84, 85, 87 and 111. The maximum value of erosion was $-0.75 \mathrm{~m} / \mathrm{yr}$ which was observed in transect ID 84 . The maximum value of accretion was $7.67 \mathrm{~m} / \mathrm{yr}$ which was observed in transect ID 16.The average of all erosional rates was $-0.75 \mathrm{~m} / \mathrm{yr}$. The average of all accretional rates was $3.51 \mathrm{~m} / \mathrm{yr}$. The average considering all transects was $3.44 \mathrm{~m} / \mathrm{yr}$. 


\subsubsection{EPR VS LRR for Winter}

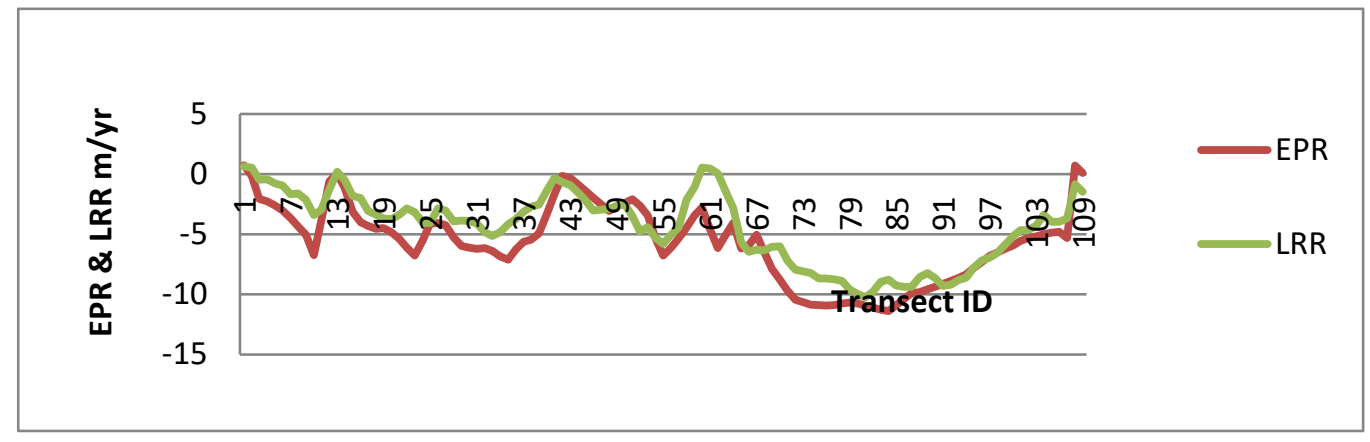

Figure 10 Transect ID Vs EPR Vs LRR for Winter

While comparing the result of EPR and LRR rates, Fig 10 shows LRR values are the low compared to EPR values. In EPR $96 \%$ of transects shows erosion while in LRR it reduce to $94 \%$ through the values vary greatly, it also intersects at some points $(13,65,95)[11]$. Approximately, the first half of the transects shows higher values compared to the other half of the transects. Erosional peak value was deserved in transect no.115 through EPR analysis.

\subsubsection{EPR Vs LRR for Summer}

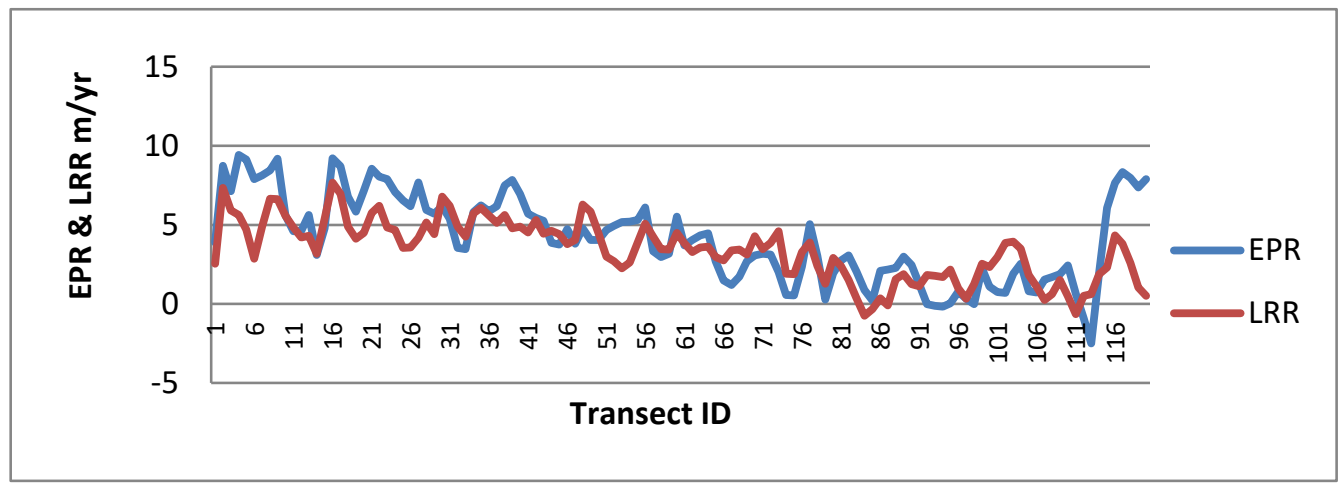

Figure 11 Transect ID Vs EPR Vs LRR for Summer

While comparing the result of EPR and LRR rates, Fig 11 shows the LRR values are the low compared to EPR values. In EPR 95\% of transects shows accretion while in LRR it increases to $96 \%$ through the values vary greatly, it also intersects at some points $(35,98$, 102) [11].Approximately, the first half of the transects shows higher values compared to the other half of the transects. Erosional peak value was deserved in transect no.115 through EPR analysis.

\subsubsection{Net Shoreline Movement for Winter}

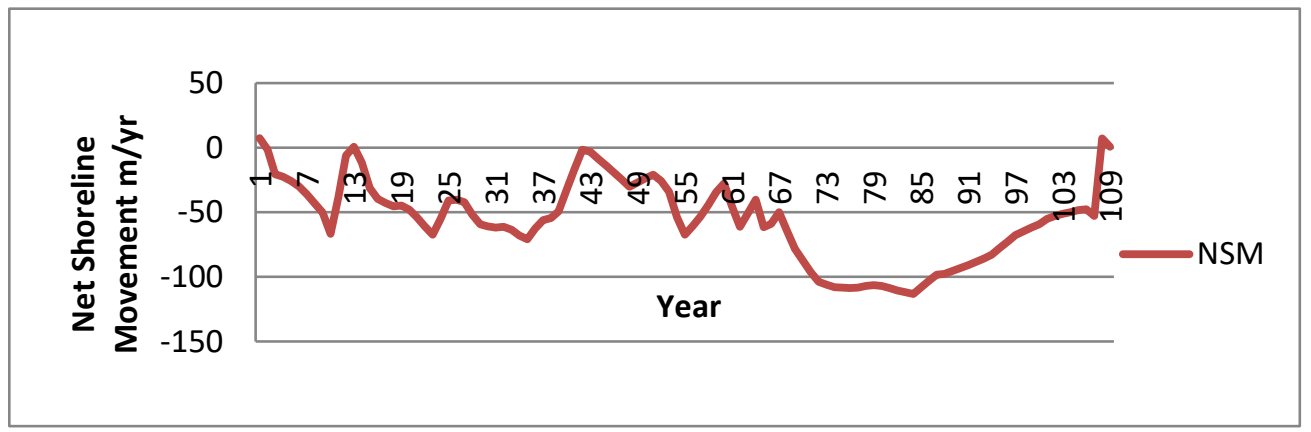

Figure 12 Year Vs Net Shoreline Movement for Winter 
Net Shoreline Movement analysis is an short term analysis method. It is very less accurate. Here the marina shoreline is around 6Km which is divided into 109 transects. Fig 12 shows both erosion and accretion were observed but majority shows erosion which was observed in 105 transects, only 4 transects shows accretion. They are 1, 13, 108 and 109. The maximum value of erosion was $-113.25 \mathrm{~m}$ which was observed in transect ID 84 . The maximum value of accretion was $7.38 \mathrm{~m}$ which was observed in transect ID 1 . The average of all erosional rates was $-58.25 \mathrm{~m}$. The average of all accretional rates was $4.03 \mathrm{~m}$. The average considering all transects was $-55.96 \mathrm{~m}$.

\subsubsection{Net Shoreline Movement for Summer}

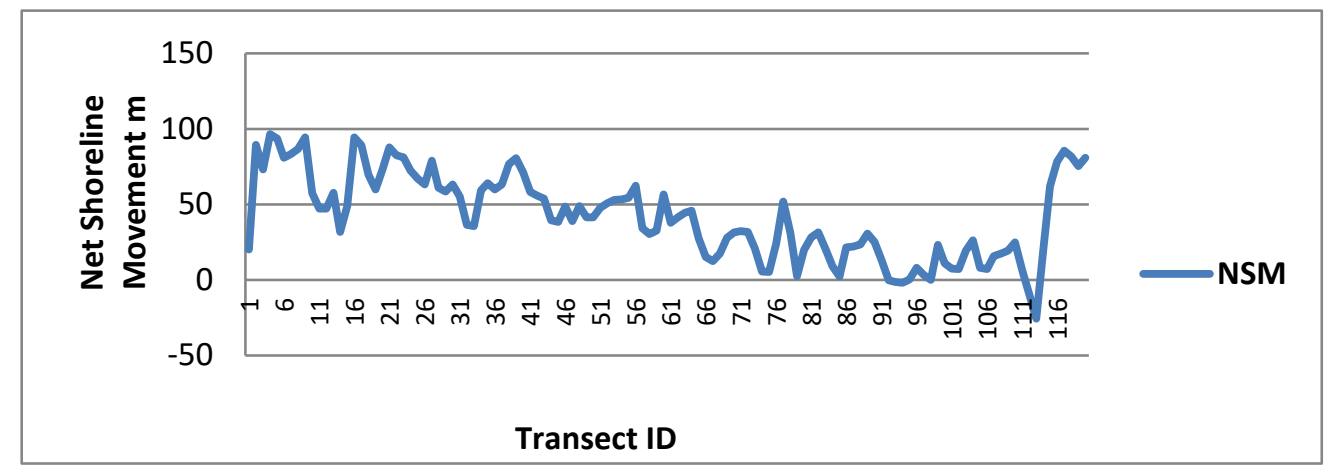

Figure 13 Year Vs Net Shoreline Movement for Summer

Net Shoreline Movement analysis is a short term analysis method. It is very less accurate. Here the marina shoreline is around $6 \mathrm{Km}$ which is divided into 120 transects. Fig 13 shows both erosion and accretion were observed but majority shows accretion which was observed in 114 transects, only 6 transects shows erosion. They are 92, 93, 94, 98, 112 and 113. The maximum value of erosion was $-25.64 \mathrm{~m}$ which was observed in transect ID 113 . The maximum value of accretion was $96.54 \mathrm{~m}$ which was observed in transect ID 4. The average of all erosional rates was $-6.38 \mathrm{~m}$. The average of all accretional rates was $44.72 \mathrm{~m}$. The average considering all transects was $42.17 \mathrm{~m}$.

\subsubsection{Net Shoreline Movement for Summer}

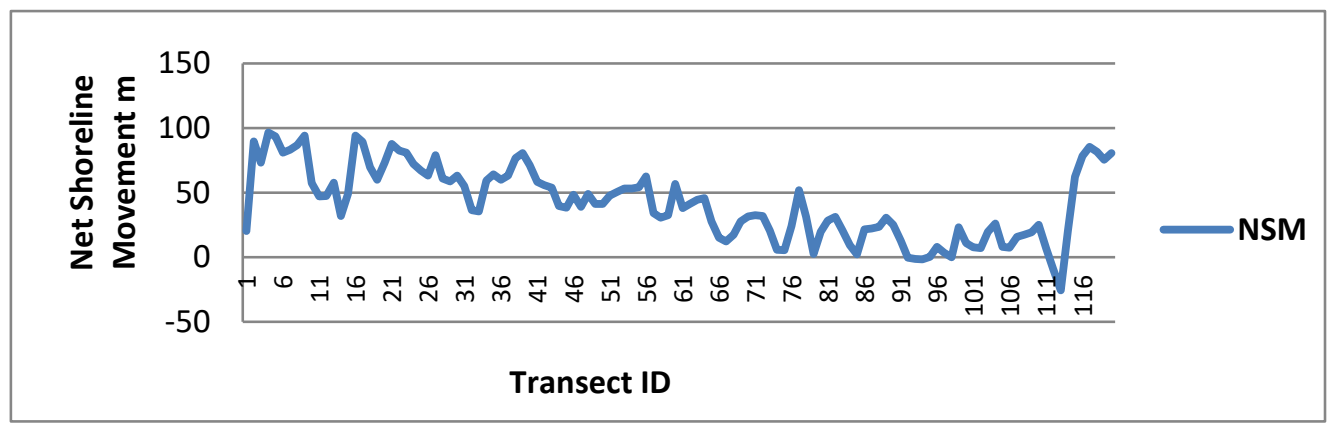

Figure 14 Transect ID Vs Net Shoreline Movement for Summer

Net Shoreline Movement analysis is also a short term analysis method. It is very less accurate. Here the marina shoreline is around $6 \mathrm{Km}$ which is divided into 120 transects. Fig 14 shows both erosion and accretion were observed but majority shows accretion which was observed in 114 transects, only 6 transects shows erosion. They are 92, 93, 94, 98, 112 and 113. The maximum value of erosion was $-25.64 \mathrm{~m}$ which was observed in transect ID 113 . The maximum value of accretion was $96.54 \mathrm{~m}$ which was observed in transect ID 4.The average of all erosional rates was $-6.38 \mathrm{~m}$. The average of all accretional rates was $44.72 \mathrm{~m}$. The average considering all transects was $42.17 \mathrm{~m}$. 


\subsection{Spatio-Temporal Analysis}

\subsubsection{Shoreline Shift Analysis for Winter}
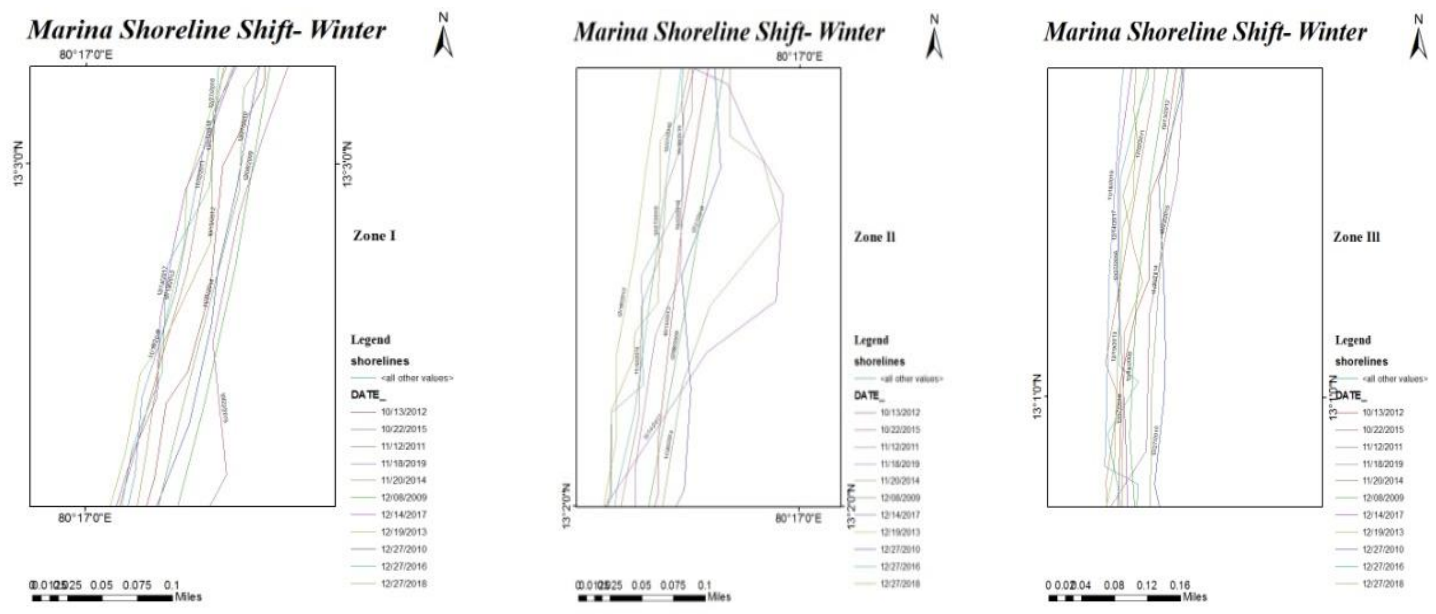

Figure 15 Marina Shoreline Shift Winter Zone I, II, III.

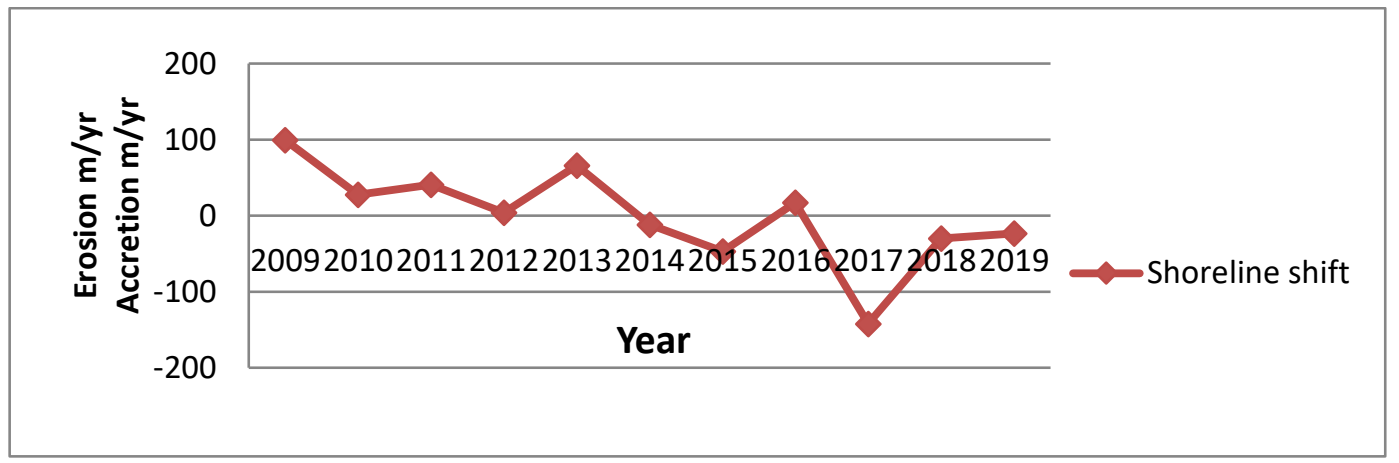

Figure 16 Marina Shoreline Shift Winter Graph.

The shoreline in the study area has never been constant and shows a continuous changing pattern. The temporal intervals used in the study for assessing the changes have been uniform. The shoreline was classified into three zones as shown in Fig 16 shows the shoreline shift over the years in winter season. On deserving the graph, 2009 shows the maximum accretion and 2017 shows the maximum erosion, whereas 2012, 2014 and 2016 remains stable sign. 2009, 2013 and 2017 shows great variation of more than 50m.

\subsubsection{Shoreline Shift Analysis for Summer}

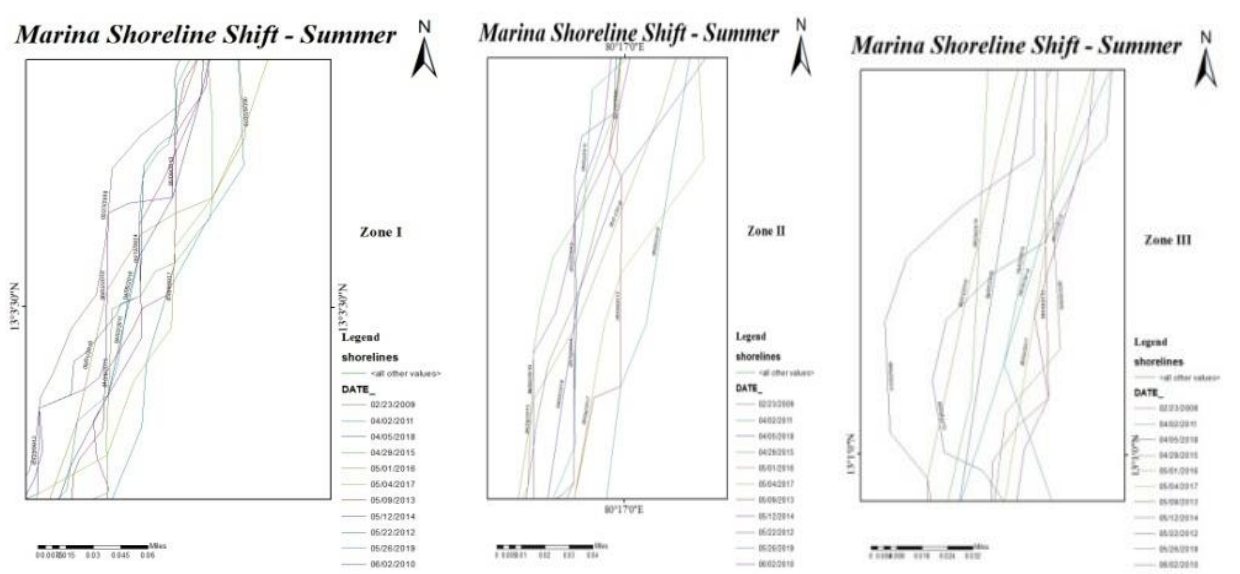

Figure 17 Marina Shoreline Shift summer Zone I, II, III 
The shorelines are classified into three zones as shown in Fig 17 shows the shoreline shift over the years in summer season. Observing the graph, summer shoreline vary drastically compared to winter shoreline 2016 shows the maximum accretion and 2012 shows the maximum erosion. Erosion pattern was only observed in 2010, 2011 and 2012. 2009 and 2016 shows higher values of accretion while 2013, 2014, 2015, 2017, 2018 and 2019 shows lower value of accretion around $50 \mathrm{~m}$.

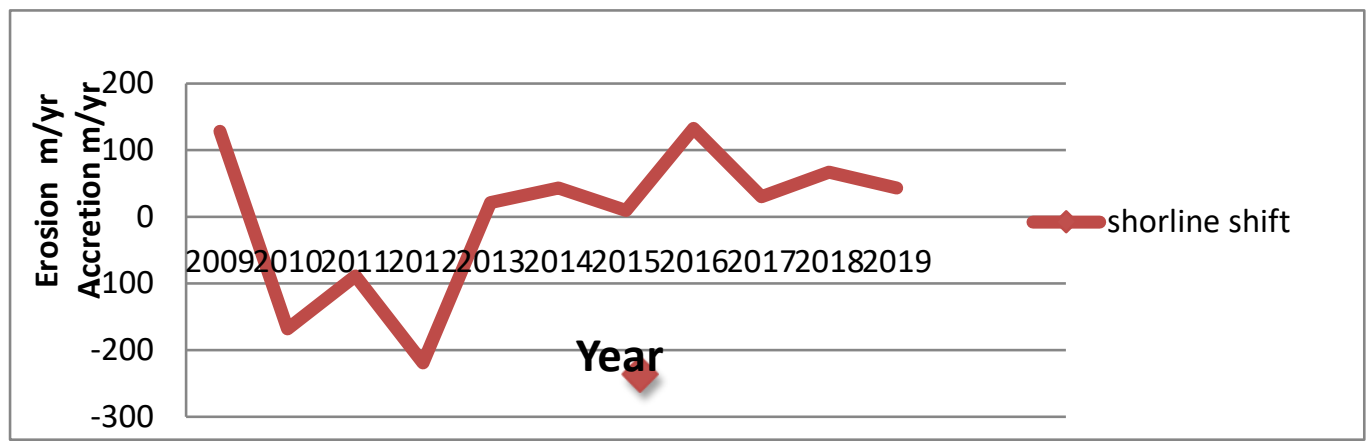

Figure 18 Marina Shoreline Shift Summer Graph.

\section{SUMMARY}
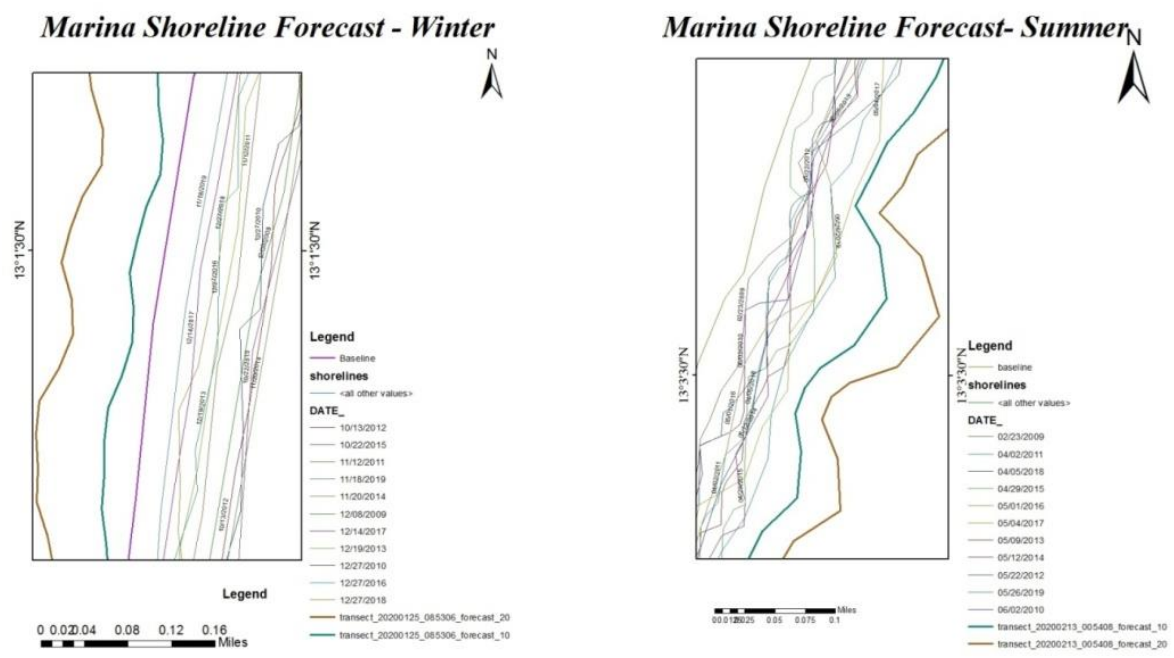

Figure 19 Marina Shoreline Forecast for winter Figure 20 Marina Shoreline Forecast for Summer

Marina shoreline change has been forcasted using the beta-forecasting in DSAS tool for the upcoming years of 2030 and 2040 only.

- Fig 19 shows the marina shoreline forecasting in Winter season.

- Fig 20 shows the marina shoreline forecasting in Summer season.

\section{ACKNOWLEDGEMENTS}

We wish to convey gratitude to our beloved Principal, Dr. Vaddi Seshagiri Rao, M.E., M.B.A., Ph.D., Dr. L. Balamurugan, M.E., Ph.D., Professor and Head of the Department In charge, Department of Civil Engineering, St. Joseph's College of Engineering, Chennai for their constant support throughout the project. This is a great pleasure to express our deep sense of gratitude and thanks to our guide Mr. S. Thangaperumal, M.Tech., for his effective support and continued encouragement, which enabled for successful completion of the 
project. We are also hereby to express our sincere thanks to all the Staff members of Civil Engineering Department for their guidance and suggestions for this project.

\section{REFERENCES}

[1] Komariah Ervita, Muh Aris Marfai (2017) "Shoreline Change Analysis in Demak, Indonesia"

[2] Muhammad Ahsan Mahboob and Iqra Atif (2016) "Coastline Change Detection Using Moderate Resolution Satellite Imagery: A Case Study Of Makran Coast, Arabian Sea, Pakistan"

[3] R.Kannan, Dr. Abhrankash Kanungo, MV Ramana (2016) “ Shoreline Change Monitoring in Nellore Coast at East Coast Andhra Pradesh District using Remote Sensing and GIS"

[4] R. Vidya, R. S. Biradar, A.B. Inamdar Sudha Srivastava and Madhavi Pikle (2015) "Assessment of shoreline changes of Alibag coast (Maharashtra, India) using remote sensing and GIS"

[5] S. Kumaravel, T. Ramkumar, Gurunanam.B, M. Suresh, Daranirajan .K (2013) An Application of Remote Sensing and GIS Based Shoreline Change Studies- "A Case Study in the Cuddalore District, East Coast of Tamilnadu, South India"

[6] Richa Choudary, R. Gowthaman, V. Sanil Kumar (2013) "Shoreline change detection from karwar to Gokarna-south west coast of India using remote sensing data"

[7] Santra Mitra S, Santra A, Mitra D (2013) "Change detection analysis of the shoreline using Toposheet and Satellite Image: A case study of the coastal stretch of Mandarmanihankarpur, West Bengal, India"

[8] S. Chethamilselvan, R.S. Kankara, B. Rajan (2013) "Assesment of Shoreline Changes Along Karnataka Coast,india Using Remote Sensing And GIS"

[9] S. Kaliraj , N. Candrasekar, N. S. Magesh (2013) "Evaluation of coastal erosion and accretion processes along the south west coast of Kanyakumari, Tamil Nadu using geospatial techniques"

[10] Mageswaran T, Ram Mohan V, Chenthamil Selvan S , Arumugam T ,Tune Usha and Kankara R.S (2015) Assessment of shoreline changes along Nagapattinam coast using geospatial techniques"

[11] Pritam Chand, Prasenjit Acharya (2010) "Shoreline change and sea level rise along coast of Bhitarkanika wildlife sanctuary, Orissa: An analytical approach of remote sensing and statistical techniques"

[12] Kumar, A. and Jayappa K. S (2008) "Long and Short-Term Shoreline Changes Along Mangalore Coast, India"

[13] Richa Choudhary, Gauthaman, Sanil kumar (2013) "Shoreline detection changes from Karwar to Gokarna - south west coast of India using remotely sensed data"

[14] Vassilakis Emm, Tsokos A and Kotsi E (2016) "Shoreline change detection and coastal erosion monitoring using digital processing of a time series of high spatial resolution Remote Sensing data (Greece)"

[15] T. W. S. Warnasuriya ,Kuddithamby Gunaalanb, and S. S. Gunasekarac(2018) "A New Resource for Shoreline Change Estimation-Case Study from Jaffna Peninsula, Sri Lanka"

[16] Karim Nassar, Wael Elham Mahmod, Hassan Fath, Ali Masria, Kazuo Nadaoka \& Abdelazim Negm (2018) "Shoreline change detection using DSAS technique: Case of North Sinai coast, Egypt" 
[17] Md. Shakil Khan, Jewel Das and Md. Humayain Kabir (2019) "Monitoring Coastline Changes in the Coastal Belt of Chittagong in Bangladesh Using GIS and Remote Sensing"

[18] B. Deepika, K Avinash, K. S. Jayappa (2012) "Shoreline change rate estimation and its forecast: Remote Sensing, geographical information system and statistics-based approach"

[19] Raju Aedlaa, Dwarakish G,D Venkat Redd (2015) "Automatic Shoreline Detection and Change Detection Analysis of Netravati-GurpurRivermouth Using Histogram Equalization and Adaptive Thresholding Techniques" 